\title{
Theft and Mutilation of Library Materials
}

\section{Terri L. Pedersen}

Periodical and book theft and mutilation are problems encountered by most academic libraries. Not only do these problems anger and frustrate library staff and patrons, but also it is expensive to replace damaged and stolen materials.

Through a questionnaire study at Emporia State University, an attempt was made to determine the answers to several questions and concerns. Behind these questions are the underlying assumptions that periodical and book theft and mutilation occur as a result of several circumstances, such as students' unfamiliarity or dissatisfaction with the library and its services, lack of knowledge about replacement time and costs, lack of concern about the needs of others, and little thought about the act of crime.

ccording to research, the problem of periodical and book theft and mutilation is laying waste to vital and expensive library collections throughout the country. Too often the damage is done quietly and is not discovered until long after the act has taken place. Damage ranges from a few pages to entire books and journals. Information is scarce on why theft and mutilation occur and on how much they cost libraries. From 1972 to 1987, less than fifteen articles and papers have been written on the subject. Very few studies have been undertaken.

\section{REVIEW OF RELATED RESEARCH}

In the early 1970 s Ron G. Martin, a librarian at Kearney State College in Nebraska, surveyed libraries. He received responses from ninety-two of them regarding instances of periodical mutilation. Eighty percent reported considerable damage to periodicals. Forty-seven percent said that they replaced mutilated periodicals with microforms. ${ }^{1}$

Around the same time, another study was conducted by Mary Noel Gouke and Marjorie Murfin. It was undertaken three years after the conclusion of a widespread publicity campaign. Their purpose was to determine the extent and cost of periodical mutilation at the library in which they worked and to locate possible solutions. They discovered that the rate of mutilation of periodicals was 15 percent. This amounted to 1,295 issues annually with $\$ 7,700$ to $\$ 12,950$ spent on repair. The authors also estimated that in the previous ten years $\$ 13,860$ to $\$ 23,100$ was spent for 2,310 issues. They also found that the public relations campaign was a viable method of reducing periodical mutilation and that the presence of damaged periodicals led to more mutilation. Among the preventive methods used were signs stating that there would be no replacement of lost articles, offers of better copiers, and the beginning of a copy machine loan fund. ${ }^{2}$

A study was also undertaken at Kent State University in 1973 by Clyde Hendrick and Marjorie Murfin in which 168 students were issued questionnaires assessing their knowledge of and opinions

Terri L. Pedersen is Assistant Head of Reference at Emporia State University, Emporia, Kansas 66801. 
about periodical mutilation. The respondents were enrolled in introductory psychology and social psychology classes at the institution. The first portion of the questionnaire dealt with personal information; familiarity with the library; and attitudes toward mutilation, copier use, penalties, and replacement. The closing section asked for opinions about possible solutions. The students were also given the option of signing their questionnaire so that Hendrick and Murfin could identify and interview professed mutilators. ${ }^{3}$

In 1978 Dana Weiss attempted to replicate the Murfin-Hendrick study. She surveyed 201 students and found that mutilation involved good students who were motivated by academic pressure. However, no connection was discovered between a student's attitude toward the library and the acts of theft and mutilation. Also, her theory that more photocopy machines might alleviate the problem was not supported. ${ }^{4}$

In 1981 the University of Nebraska at Omaha reported a rise in mutilation and theft. During the year 1,000 magazine pages and 672 complete issues had to be replaced. To combat the problem, the library launched a public relations campaign alerting students to the fact that mutilation is a crime. ${ }^{5}$

Collectively these studies demonstrate that all libraries encounter the problem of mutilation and theft. The damage is especially troublesome for academic libraries and leads to costly damage that causes frustration for both patrons and library staff members. The present study was conducted because a need exists for research into the causes and prevention of mutilation and theft in libraries.

There were four major goals of the study. The desired result of the project was to discover the answers to inquiries related to these stated goals:

1. Through the examination of the attitudes and characteristics of students who mutilate and steal as compared with those who do not, to uncover the reasons why theft and mutilation occur.

2. In discovering the reasons for and circumstances surrounding the theft and mutilation of library materials, to find out how it is accomplished.

3 . By looking at the proportion of students involved in theft and mutilation of periodicals or books, to discover who is responsible.

4. Finally, to locate preventive methods that students feel would be good deterrents to the problem of mutilation and theft.

\section{METHODOLOGY OF DATA COLLECTION}

The study was conducted during the 1988 spring semester at Emporia State University. At that time the school had an enrollment of 5,134 students. As in the Hendrick-Murfin and Weiss studies, it was determined that an anonymous questionnaire would yield the greatest results. It was in the selection of the sample that this study deviates from the previous two. In those studies, the methods of obtaining students were limited, thus biasing their results. The test group and final data were thrown off by a young population that was mainly female. In this project, an attempt was made to choose a sample that was more representative of the entire student population. Courses were randomly selected from each subject division making up the university structure.

The questionnaires were administered to the students during class time, with the permission of the instructor. This method was chosen to help ensure a high survey return. Sixteen classes were visited with the questionnaire during a two-week period. It was administered to 235 students. Data analysis is based upon the results from those respondents. The questionnaire is located at the end of this article.

\section{RESULTS}

The first section describes the makeup of the sample. The next section presents the results of the questionnaire and compares those who admitted to being involved in theft and mutilation (violators) and those not involved (nonviolators).

\section{Characteristics of the Sample}

The 235 students surveyed represented approximately 5 percent of the total population of the university. Of the 235 stu- 
dents $54 \%$, or 122 , were female and $46 \%$, or 104 , were male. This came fairly close to the university's ratio of $60 / 40$, as shown in the figure 1 . The sample population was also very close to the university's totals in regard to student grade classification. The breakdown was as follows: freshmen, 65 , or $28 \%$; sophomores, 41 , or $17 \%$; juniors, 61 , or $26 \%$; seniors, 54 , or $23 \%$, and graduate students, 14 , or $6 \%$. The university class breakdown was $18 \%, 13 \%, 16 \%$, $18 \%$, and $32 \%$, respectively. The obvious downfall in the sampling was the low questioning of graduate students, which could have been avoided by visiting more graduate courses. The students involved in the survey were fairly evenly spread between the ages of 18 and 23 , with only $13 \%$ of the sample over the age of 25 . The students were also from the various colleges, with the highest percentages in either the school of business or the teachers college, which was not overly surprising.

Two of the most significant questions asked if the students had ever stolen books or magazines from the library or if they had ripped out pages. Twenty-four students admitted ripping out pages and 11 confessed to stealing library materials. Only 6 students circled yes to both questions, for a total of 29 violators, $12 \%$ of the sample surveyed. Of this group of viola-
ACTUAL POPULATION

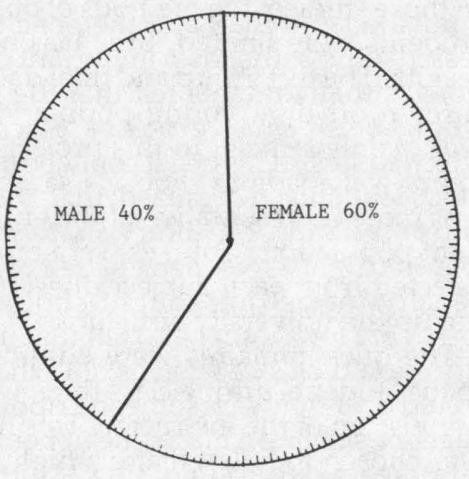

ACTUAL POPULATION

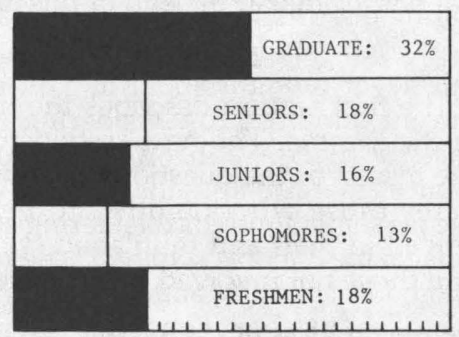

SAMPLE POPULÁTION

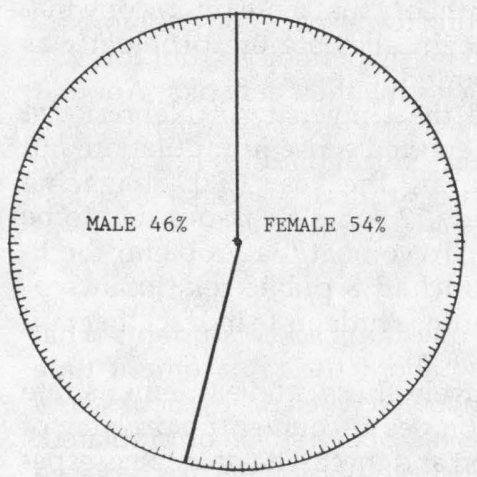

SAMPLE POPULATION

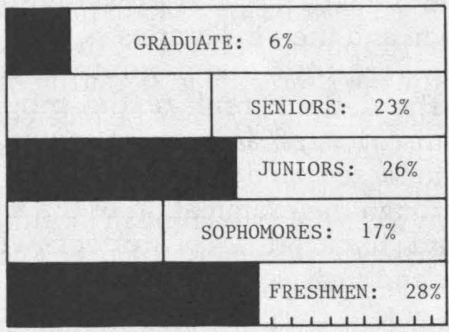

FIGURE 1

Survey Sample in Comparison with Actual University Population

(Total University Enrollment, Spring 1988, = 5,134; Research Sample $=235$, or 5 Percent) 
tors, most were involved in fewer than five instances.

One goal was to determine whether a violator differed drastically from a nonviolator and to devise a composite sketch of a violator. The belief was that those involved would be younger students with poor to average grades, lacking responsibility and looking for an easy way out. What emerged as the typical violator was a male or female student, aged 20-22, junior or senior, with a G.P.A. in the 2.0-2.9 range.

One important fact was that students do not spend much time in the library. The study indicated that those spending more time in the library were less likely to damage and steal library materials. Most students also admitted to writing very few papers in their college career. Seventyfive percent completed less than ten. Students writing fewer papers were more inclined to damage periodicals, but this was not as true for the theft of books. Another interesting fact is that paying for one's own college education does not seem to make a student more responsible or less likely to mutilate and steal.

\section{Replacement}

Several questions asked students what they knew about the replacement time and cost involved when pages, books, and periodicals have been stolen or mutilated. Students believe that things are replaced fairly easily. This usually only holds true for magazine articles and book pages that are missing and not entire books and periodicals. Students made a good guess at the replacement cost and time when only the pages were missing. Most missing pages at Emporia State are ordered through the interlibrary loan department. These replacement pages may be received in a month, and $66 \%$ of the students answered this question accurately. The cost usually involves only staff time in locating and ordering replacement pages. This probably averages $\$ 5$ to $\$ 10$, which was the response of $48 \%$ of the students. In terms of replacing entire books and whole periodicals, the sample perceived it as being easier than it actually is. Only $16 \%$ of the students answered that replacements may never be found and bought. Most students $(62 \%)$ felt that materials could be replaced within a three-month period. When it comes to changing the perceptions of students regarding periodical and book theft and mutilation, information concerning replacement costs and time should probably be used in a campaign. Perhaps if more patrons realized that items may not be replaced, they might think before acting rashly. In terms of cost, $84 \%$ of the students felt that stolen items could be replaced for under ten dollars. Once again, this is an area where the students' beliefs need to be changed (see table 1).

\section{Perceptions of the Problem and Penalties}

A major group of questions involved students' perceptions of the problem of mutilation and theft and the penalties assessed. One of the most important conclusions is that students felt that the library would be or is a very easy place from which to steal. This belief could be altered. Most students recognized that the theft and mutilation of library materials are crimes. Eighty-two percent felt that the penalty for getting caught should be a fine. Very few (under $4 \%$ ) felt that no penalty should exist. When asked what they would do if they saw someone ripping out pages or stealing a magazine or book, $61 \%$ said they would do nothing. Thirty percent indicated they would report it, and the remaining $9 \%$ would either tell the offender what they were doing was wrong or ask them to stop.

When asked if they had ever considered tearing out articles or pages from a book, most of the students (56\%) said that they had never thought about it. Thirty-eight percent admitted to considering the act once or twice, with only $6 \%$ thinking about it more than a few times. Twentyfive percent admitted considering stealing a magazine or book, while $75 \%$ never considered it. When admitted violators were asked about their concerns for getting caught in the act, $50 \%$ were not concerned at all, $34 \%$ were mildly to moderately concerned, and only $16 \%$ were very worried about someone catching them. 
TABLE 1

RESULTS ON LIBRARY USE AND PERCEPTIONS OF THE PROBLEM

\begin{tabular}{|c|c|c|c|c|}
\hline Question & & $\begin{array}{l}\text { Non- } \\
\text { Ripoffs } \\
(\%)\end{array}$ & $\begin{array}{l}\text { Thieves } \\
(\%)\end{array}$ & $\begin{array}{c}\text { Page } \\
\text { Rippers } \\
(\%)\end{array}$ \\
\hline \multicolumn{5}{|l|}{ Library use } \\
\hline A. Number of term & $0-9$ & 74 & 36 & 80 \\
\hline papers done so & 10-19 & 20 & 46 & 16 \\
\hline far in college & $20+$ & 6 & 18 & 4 \\
\hline \multirow{3}{*}{$\begin{array}{l}\text { B. Amount of times } \\
\text { one goes to the }\end{array}$} & Almost never & 41 & 82 & 33 \\
\hline & 1-5 times weekly & 55 & 9 & 63 \\
\hline & Daily & 4 & 9 & 4 \\
\hline \multirow{3}{*}{$\begin{array}{l}\text { C. Hours a week } \\
\text { spent in the } \\
\text { library }\end{array}$} & & 30 & 36 & 17 \\
\hline & $\begin{array}{l}1-5 \\
6-15\end{array}$ & 55 & $\begin{array}{r}55 \\
0\end{array}$ & $\begin{array}{r}75 \\
4\end{array}$ \\
\hline & $\begin{array}{l}6-15 \\
16+\end{array}$ & 3 & 9 & $\begin{array}{l}4 \\
4\end{array}$ \\
\hline \multicolumn{5}{|c|}{ Perceptions on Theft and Mutilation of Library Materials } \\
\hline \multirow{2}{*}{$\begin{array}{l}\text { A. How easy would it } \\
\text { be to tear out an }\end{array}$} & Very easy & 61 & 90 & 63 \\
\hline & Somewhat difficult & 28 & 10 & $\begin{array}{r}29 \\
8\end{array}$ \\
\hline article or to steal & Moderately difficult & 8 & 0 & 8 \\
\hline library materials? & Very difficult & 3 & 0 & 0 \\
\hline B. What is the penalty & None & 20 & 36 & 35 \\
\hline \multirow{2}{*}{$\begin{array}{l}\text { for theft and mutil- } \\
\text { ation of library } \\
\text { items? }\end{array}$} & $\begin{array}{l}\text { Misdemeanor } \\
\text { Higher than }\end{array}$ & 72 & 46 & 57 \\
\hline & Misdemeanor & 8 & 18 & 8 \\
\hline \multirow{3}{*}{$\begin{array}{l}\text { C. What should the } \\
\text { penalty be? }\end{array}$} & None & 2 & 18 & 17 \\
\hline & Fine & 83 & 82 & $\begin{array}{r}75 \\
8\end{array}$ \\
\hline & $\begin{array}{l}\text { More severe } \\
\text { Nothing }\end{array}$ & $\begin{array}{l}15 \\
59\end{array}$ & $\begin{array}{r}0 \\
91\end{array}$ & $\begin{array}{r}8 \\
88\end{array}$ \\
\hline \multirow{3}{*}{$\begin{array}{l}\text { D. If you saw someone } \\
\text { violating library } \\
\text { materials, what } \\
\text { would you do? }\end{array}$} & Tell them it's wrong & & & \\
\hline & and ask to stop & 8 & 9 & 4 \\
\hline & Report it & 33 & 0 & 8 \\
\hline \multirow{3}{*}{$\begin{array}{l}\text { E. Time to replace } \\
\text { a torn out } \\
\text { article }\end{array}$} & Less than 1 month & 48 & 54 & 59 \\
\hline & 1-6 months & 39 & 28 & 29 \\
\hline & Over 6 months & 13 & 18 & 12 \\
\hline \multirow{4}{*}{$\begin{array}{l}\text { F. Time to replace } \\
\text { a stolen magazine }\end{array}$} & Less than 1 month & 30 & 46 & 46 \\
\hline & $1-6$ months & 43 & 18 & 30 \\
\hline & Over 6 months & 10 & 9 & 11 \\
\hline & Never Replaced & 17 & 27 & 13 \\
\hline \multirow{3}{*}{$\begin{array}{l}\text { G. Cost to the library } \\
\text { to replace torn } \\
\text { pages }\end{array}$} & $\$ 1$ and under & 27 & 55 & 54 \\
\hline & $\$ 5-\$ 10$ & 51 & 27 & 21 \\
\hline & Over \$15 & 22 & 18 & 25 \\
\hline \multirow{3}{*}{$\begin{array}{l}\text { H. Cost to replace a } \\
\text { stolen book or } \\
\text { magazine }\end{array}$} & Under $\$ 10$ & 84 & 91 & 96 \\
\hline & $\$ 15-\$ 20$ & 11 & 9 & 0 \\
\hline & Over $\$ 20$ & & 0 & 4 \\
\hline \multirow[b]{4}{*}{ magazines or books? } & Never & 32 & 63 & 42 \\
\hline & One in a while & 56 & 27 & 50 \\
\hline & Quite often & 10 & 10 & 4 \\
\hline & All the time & 2 & 0 & 4 \\
\hline \multirow{4}{*}{$\begin{array}{l}\text { J. Have you ever } \\
\text { considered tearing } \\
\text { out an article or } \\
\text { book pages? }\end{array}$} & & 60 & 18 & 17 \\
\hline & Once or twice & 36 & 37 & 63 \\
\hline & Occasionally & & 27 & 12 \\
\hline & All the time & 1 & 18 & 8 \\
\hline \multirow{4}{*}{$\begin{array}{l}\text { K. Have you ever } \\
\text { considered stealing } \\
\text { a magazine or } \\
\text { book? }\end{array}$} & Never & 76 & 9 & 54 \\
\hline & Once or twice & 22 & 64 & 33 \\
\hline & Occasionally & 2 & 9 & 4 \\
\hline & All the time & 0 & 18 & 9 \\
\hline \multirow{4}{*}{$\begin{array}{l}\text { L. What percentage of } \\
\text { the student body is } \\
\text { involved in theft } \\
\text { and mutilation? }\end{array}$} & $0-15 \%$ & 51 & 18 & 20 \\
\hline & $15-30 \%$ & 29 & 27 & 42 \\
\hline & $30-50 \%$ & 15 & 18 & 17 \\
\hline & Over $50 \%$ & 5 & 37 & 21 \\
\hline
\end{tabular}


Of the 235 students questioned, only $33 \%$ said that they had never been inconvenienced by missing or torn-out pages. Fifty-five percent had been bothered once in a while, and $12 \%$ were either inconvenienced quite often or all of the time. Of the violators, only $58 \%$ had ever been inconvenienced through stolen or damaged periodicals or books.

In the sampling of the student population, only $10 \%$ admitted to periodical and book theft or mutilation. When students were asked to estimate what percentage of the student body might rip out articles or steal books or magazines: $18 \%$ answered under $5 \%$; $30 \%$ responded with $5-15 \%$; $30 \%$ also marked $15-30 \%$; and $28 \%$ felt that over $30 \%$ of the student body might be involved in the theft and damage. Students who admitted to being violators were more inclined to believe that a large percentage of the students were involved in theft and mutilation.

\section{Opinions on the Reasons} for Theft and Mutilation

Another section asked students why they thought books and periodicals were mutilated and stolen (see table 2). They were to circle as many responses as they felt correct. Seventy-eight percent of the nonviolators felt that students did not consider the needs of others, as compared with $83 \%$ of the violators. Few respondees believed that students were unable to afford the copy machine or the price of the book, with only $36 \%$ of the nonviolators and $50 \%$ of the violators answering yes to that question. Because more violators felt this was true, it may explain why some were involved in the damage. When asked if students were aware of the cost of the theft and mutilation to the library, 55 percent of both the violators and nonviolators felt that this was a problem. Again, both groups were in agreement when asked if students need the photographs or charts that could not be copied. Only $30 \%$ in each group answered yes to this question, indicating a problem. When asked if mutilation and theft were done casually and thoughtlessly, $52 \%$ of the nonviolators felt this was true. A big difference was shown in the responses of the violators. Fifty-five percent of the article and page rippers felt that it was done thoughtlessly,

TABLE 2

QUESTION: BOOKS AND PERIODICALS ARE STOLEN AND MUTILATED BECAUSE STUDENTS . . .

\begin{tabular}{|c|c|c|c|c|}
\hline & & $\begin{array}{c}\text { Thieves } \\
(\%)\end{array}$ & $\begin{array}{l}\begin{array}{l}\text { Responses } \\
\text { Page Rippers } \\
(\%)\end{array} \\
\end{array}$ & $\begin{array}{c}\text { Nonviolators } \\
\text { (\%) }\end{array}$ \\
\hline $\begin{array}{l}\text { A. Do not consider the } \\
\text { needs of others }\end{array}$ & $\begin{array}{l}\text { (T) } \\
\text { (F) }\end{array}$ & $\begin{array}{l}72 \\
28\end{array}$ & $\begin{array}{l}83 \\
17\end{array}$ & $\begin{array}{l}79 \\
21\end{array}$ \\
\hline $\begin{array}{l}\text { B. Cannot afford the copy } \\
\text { machine or the price } \\
\text { of the book, but want }\end{array}$ & (F) & $\begin{array}{l}45 \\
54\end{array}$ & $\begin{array}{l}54 \\
45\end{array}$ & $\begin{array}{l}36 \\
64\end{array}$ \\
\hline $\begin{array}{l}\text { C. Are not aware of the } \\
\text { cost of theft and } \\
\text { mutilation to the } \\
\text { library }\end{array}$ & $\begin{array}{l}\text { (T) } \\
\text { (F) }\end{array}$ & $\begin{array}{l}36 \\
64\end{array}$ & $\begin{array}{l}55 \\
45\end{array}$ & $\begin{array}{l}56 \\
44\end{array}$ \\
\hline $\begin{array}{l}\text { D. Need the photographs } \\
\text { or charts and cannot } \\
\text { photocopy them }\end{array}$ & $\begin{array}{l}(\mathrm{T}) \\
(\mathrm{F})\end{array}$ & $\begin{array}{l}19 \\
81\end{array}$ & $\begin{array}{l}50 \\
50\end{array}$ & $\begin{array}{l}70 \\
30\end{array}$ \\
\hline $\begin{array}{l}\text { E. Do not think about the } \\
\text { act or the library, but } \\
\text { steal and mutilate } \\
\text { casually and thought- } \\
\text { lessly }\end{array}$ & $\begin{array}{l}\text { (T) } \\
\text { (F) }\end{array}$ & $\begin{array}{l}27 \\
73\end{array}$ & $\begin{array}{l}45 \\
55\end{array}$ & $\begin{array}{l}53 \\
47\end{array}$ \\
\hline $\begin{array}{l}\text { F. Steal and mutilate items } \\
\text { as an expression of } \\
\text { hostility toward the } \\
\text { library and university }\end{array}$ & $\begin{array}{l}\text { (T) } \\
\text { (F) }\end{array}$ & $\begin{array}{l}18 \\
82\end{array}$ & $\begin{array}{r}9 \\
91\end{array}$ & $\begin{array}{l}13 \\
87\end{array}$ \\
\hline
\end{tabular}


but only $27 \%$ of the book or magazine stealers indicated this was true. Very few students viewed theft and mutilation as an expression of hostility towards the library.

\section{Effective Preventive Methods}

Opinions were asked on which measures would be effective in eliminating the problem (see table 3 ). The only option that received an overwhelming response was the availability of free copying. Sixty-three percent of both the violators and nonviolators felt that this would help prevent the problem. Other options included the following: (1) periodicals kept on reserve for checkout $-30 \%$ for and $70 \%$ against; (2) periodicals on limited access or not able to be removed from the area- $35 \%$ for and $65 \%$ against; (3) sign warning of the penalty, $\$ 500$ fine or 30 days in jail $-45 \%$ felt this would work, while $55 \%$ said it would not; (4) signs indicating the cost and time of replacement- $32 \%$ felt this would be effective, while $68 \%$ felt it would not be; (5) a publicity campaign showing the extent of the problem and urging concern for others $-23 \%$ in favor and $77 \%$ opposed; and (6) a copying loan service or copy card bought in advance-25\% for and $75 \%$ against. Forty-five percent of the nonviolators favored checking out periodicals like books as compared with $54 \%$ of the violators.

\section{General Attitudes Concerning the Library and Its Services}

The final section of the questionnaire dealt with the library, its services, and copy machines (see table 4). Generally, students were positive toward the library $(87 \%)$. Most usually found what they needed in the library, with only $20 \%$ disagreeing. A majority felt they were treated fairly by the library, with only $18 \%$ feeling unfairly treated. When asked if the library discriminates against undergraduate students by having more lenient policies for graduate students and faculty, most of the students either disagreed or had no opinion. When asked if the library was a cold and anonymous place, $71 \%$ answered either no opinion or disagreed. It was interesting to find that 54 percent of those ad-

TABLE 3

RESULTS FOR EFFECTIVE PREVENTIVE MEASURES

\begin{tabular}{|c|c|c|c|}
\hline Measure & $\begin{array}{c}\text { Thieves, } \\
\text { Rippers, } \\
\text { Nonviolators } \\
\end{array}$ & $\begin{array}{c}\text { Effective } \\
(\%)\end{array}$ & $\begin{array}{c}\text { Not } \\
\text { Effective } \\
(\%)\end{array}$ \\
\hline A. Periodicals kept on & T & $\begin{array}{l}36 \\
33\end{array}$ & $\begin{array}{l}64 \\
67\end{array}$ \\
\hline be checked out & NV & 29 & 71 \\
\hline B. Limited access- & $\mathrm{T}$ & 36 & 64 \\
\hline $\begin{array}{l}\text { Periodicals not } \\
\text { taken from area }\end{array}$ & $\begin{array}{l}\mathrm{R} \\
\mathrm{NV}\end{array}$ & $\begin{array}{l}33 \\
35\end{array}$ & $\begin{array}{l}67 \\
65\end{array}$ \\
\hline C. Sign warning of & $\mathrm{T}$ & 64 & 36 \\
\hline $\begin{array}{l}\text { penalty: } \$ 500 \text { or } 30 \\
\text { davs in aail }\end{array}$ & $\begin{array}{l}\mathrm{R} \\
\mathrm{NV}\end{array}$ & $\begin{array}{l}46 \\
44\end{array}$ & $\begin{array}{l}54 \\
56\end{array}$ \\
\hline D. Signs indicating & $\mathrm{T}$ & 18 & 82 \\
\hline $\begin{array}{l}\text { cost and time of } \\
\text { replacement }\end{array}$ & R & 38 & $\begin{array}{l}62 \\
69\end{array}$ \\
\hline E. Periodicals could & $\mathrm{T}$ & $\begin{array}{l}31 \\
27\end{array}$ & 73 \\
\hline $\begin{array}{l}\text { be checked out like } \\
\text { books }\end{array}$ & $\begin{array}{l}\mathrm{R} \\
\mathrm{NV}\end{array}$ & $\begin{array}{l}54 \\
45\end{array}$ & $\begin{array}{l}46 \\
55\end{array}$ \\
\hline F. Publicity campaign & $\mathrm{T}$ & 0 & 100 \\
\hline $\begin{array}{l}\text { showing the extent of } \\
\text { problem and urging } \\
\text { concern for others }\end{array}$ & $\begin{array}{l}\mathrm{R} \\
\mathrm{NV}\end{array}$ & $\begin{array}{l}25 \\
22\end{array}$ & $\begin{array}{l}75 \\
78\end{array}$ \\
\hline $\begin{array}{l}\text { G. Free copying } \\
\text { available }\end{array}$ & $\mathrm{T}$ & $\begin{array}{l}45 \\
63\end{array}$ & $\begin{array}{l}55 \\
37\end{array}$ \\
\hline H. Copying loan service & NV & 63 & $\begin{array}{l}37 \\
73\end{array}$ \\
\hline or copy cards bought & $\mathrm{R}$ & 42 & 58 \\
\hline in advance & NV & 24 & 76 \\
\hline
\end{tabular}


TABLE 4

GENERAL ATTITUDES CONCERNING THE LIBRARY AND SERVICES

\begin{tabular}{|c|c|c|c|c|c|}
\hline Question & $\begin{array}{l}\text { Thieves, Rippers, } \\
\text { Nonviolators }\end{array}$ & $\begin{array}{l}\text { Agree } \\
(\%)\end{array}$ & $\begin{array}{l}\text { Somewhat } \\
\text { Agree } \\
(\%)\end{array}$ & $\begin{array}{c}\text { No } \\
\text { Opinion } \\
(\%)\end{array}$ & $\begin{array}{l}\text { Dis- } \\
\text { agree } \\
(\%)\end{array}$ \\
\hline A. In general, I feel & $\mathrm{T}$ & 36 & 55 & 0 & 9 \\
\hline $\begin{array}{l}\text { very positive toward } \\
\text { the library }\end{array}$ & $\begin{array}{l}\mathrm{R} \\
\mathrm{NV}\end{array}$ & $\begin{array}{l}67 \\
64\end{array}$ & $\begin{array}{l}25 \\
23\end{array}$ & $\begin{array}{r}4 \\
10\end{array}$ & $\begin{array}{l}4 \\
3\end{array}$ \\
\hline B. The library is a cold & & 36 & 18 & 27 & 18 \\
\hline and anonymous & $\mathrm{R}$ & 13 & 25 & 12 & 50 \\
\hline place & NV & 5 & 23 & 27 & 45 \\
\hline C. I find the library & $\mathrm{T}$ & 64 & 27 & 9 & 0 \\
\hline staff to be quite & $\mathrm{R}$ & 63 & 29 & 8 & 0 \\
\hline friendly and helpful & NV & 39 & 38 & 15 & 8 \\
\hline D. I always find & $\mathrm{T}$ & 18 & 45 & 27 & 9 \\
\hline $\begin{array}{l}\text { what I need in } \\
\text { the library }\end{array}$ & $R$ & 39 & 52 & 4 & 4 \\
\hline $\begin{array}{l}\text { the library } \\
\text { E. I have been treated }\end{array}$ & $\underset{T}{\mathrm{NV}}$ & $\begin{array}{r}16 \\
9\end{array}$ & $\begin{array}{l}57 \\
27\end{array}$ & $\begin{array}{r}5 \\
27\end{array}$ & $\begin{array}{l}21 \\
36\end{array}$ \\
\hline unfairly by the & $\mathrm{R}$ & 8 & 13 & 25 & 54 \\
\hline \multicolumn{6}{|l|}{ F. The library discriminates } \\
\hline against undergraduates & $\mathrm{T}$ & 18 & 9 & 36 & 36 \\
\hline because it has more & $\mathrm{R}$ & 0 & 17 & 50 & 33 \\
\hline $\begin{array}{l}\text { lenient policies for } \\
\text { grads and faculty }\end{array}$ & NV & 6 & 12 & 52 & 30 \\
\hline \multirow{2}{*}{$\begin{array}{l}\text { G. Copy machines are } \\
\text { too expensive }\end{array}$} & & 46 & 18 & 18 & 18 \\
\hline & $\stackrel{\mathrm{R}}{\mathrm{NV}}$ & $\begin{array}{l}50 \\
44\end{array}$ & $\begin{array}{l}29 \\
23\end{array}$ & $\begin{array}{r}0 \\
17\end{array}$ & $\begin{array}{l}21 \\
16\end{array}$ \\
\hline \multirow{3}{*}{$\begin{array}{l}\text { H. Copy machines } \\
\text { take too long } \\
\text { to use }\end{array}$} & $\mathrm{T}$ & 9 & 18 & 18 & 55 \\
\hline & $\mathrm{R}$ & 8 & 25 & 17 & 50 \\
\hline & $\mathrm{NV}$ & 9 & 13 & 23 & 55 \\
\hline \multirow{2}{*}{$\begin{array}{l}\text { I. The copy machines } \\
\text { are usually out } \\
\text { of order }\end{array}$} & $\stackrel{T}{R}$ & 18 & $\begin{array}{l}46 \\
54\end{array}$ & $\begin{array}{r}27 \\
8\end{array}$ & $\begin{array}{r}9 \\
21\end{array}$ \\
\hline & NV & 17 & 34 & 28 & 21 \\
\hline \multirow[b]{3}{*}{ periodicals } & $\mathrm{T}$ & 27 & 9 & 18 & 46 \\
\hline & $\mathrm{R}$ & 8 & 25 & 25 & 42 \\
\hline & NV & 1 & 9 & 24 & \\
\hline \multirow{3}{*}{$\begin{array}{l}\text { K. No harm is done since } \\
\text { no one else will need } \\
\text { that particular item }\end{array}$} & $\mathrm{T}$ & 9 & 18 & 9 & \\
\hline & $\mathrm{R}$ & 4 & 13 & 17 & 66 \\
\hline & NV & 1 & 1 & 10 & 88 \\
\hline
\end{tabular}

mitting to stealing items agreed that the library was cold and anonymous. Most of those students also found the library staff to be friendly and helpful and felt positive toward the library. Basically, these questions helped library employees to know that they are viewed positively but need to work on helping patrons more in finding what they need.

Three questions were asked about the copy machines. As expected, a large majority felt that the copy machines were too expensive and usually out of order. Neither can be changed when the cost of operation and high level of use are considered. When a machine breaks down, the repairmen are contacted immediately. When asked if copy machines take too long to use, most students disagreed, so this does not seem to be a problem.

The final two questions dealt with the perceptions on mutilation and theft. It was surprising to find that $80 \%$ of the nonviolators disagreed with the statement that the library could easily replace stolen items and over $30 \%$ of the violators felt that stolen and damaged materials could be easily replaced. It was encouraging to note that $85 \%$ agreed that theft and mutilation are harmful because someone may need an item.

\section{SUMMARY}

Based on the data, the violators did not seem to differ greatly from the nonviolators. Basically, it was discovered that stu- 
dents cannot be identified as potential violators of library materials. It appears that situational circumstances lead a student to mutilation and theft. A number of the nonviolators expressed the temptation to steal pages, articles, books, or journals, thus indicating a potential group for more damage to library materials. Dana Weiss noted in her research:

Because this study was done in an urban university library, it could be said that the "toughness" of city life causes the theft. However, I believe a case could be made for "danger" on a rural college campus. . . 6

Because Emporia is in a rural area, the "toughness of city life" is not a cause of mutilation and theft. The fault does not appear to lie with the library being unfriendly, cold, and anonymous. Students did not view the theft and mutilation problem as an expression of hostility toward the institution but instead felt that their fellow students were selfish and did not consider the needs of others. In the 1980 s, the emphasis has been on the success of the individual striving for personal gain no matter what cost is involved. With the thought of academic achievement leading to professional success for the individual, there is the pressure to do well and to earn high grades. Thus, as Weiss remarked, "Good grades may serve to reinforce for . . . students that it is more important what happens in their individual careers than sensitivity to the needs of fellow students. ${ }^{\prime 7}$

The present study points to certain steps that the library can take to reduce in- stances of theft and mutilation. Staff should watch carefully for and be aware of those students having trouble using the library and possibly looking for help, thus reducing the frustration level that may ultimately lead to desperate measures. As in previous studies, the survey indicates that patrons are not really aware of the difficulty and expense involved in replacing damaged and stolen library materials. A publicity campaign could inform students of the cost associated with lost, stolen, or mutilated books and magazines. Informed students should be less likely to steal and mutilate.

Other measures are the setting of equitable penalties for violation, with signs that cite the law and list penalties. Those surveyed, however, felt that the theft and mutilation of library materials were easy to do with limited consequences and little chance of being apprehended. If students found that the theft and mutilation of library materials were more difficult to accomplish and that the penalties were stiffer and enforced, the problem would decrease. A library's lowering the cost of photocopying should diminish the problem as well.

This study has uncovered possibilities for further work, such as initiating some preventive measures and evaluating their usefulness. If preventive measures are effective, libraries will be able to overcome the costly damage that causes frustration for both patrons and library staff members. Further means to deter possible violators of library materials still need to be developed.

\section{REFERENCES}

1. Ron Martin, "Microforms and Periodical Mutilation,"' Microform Review 2:6-8 (Jan. 1973).

2. Mary Noel Gouke and Marjorie Murfin, "Periodical Mutilation: The Insidious Disease," Library Journal 105:1795-97 (Sept. 15, 1980).

3. Clyde Hendrick and Marjorie Murfin, "Project Library Ripoff: A Study of Periodical Mutilation in a University Library,' College \& Research Libraries 35:402-4 (Nov. 1974).

4. Dana Weiss, "Book Theft and Mutilation in a Large Urban University Library," College E Research Libraries 42:341-47 (July 1981).

5. "'University of Nebraska Reports Sharp Rise in Mutilation,"' Library Journal 107:2212 (Dec. 1, 1982).

6. Weiss, "Book Theft and Mutilation," p.345.

7. Ibid. 